\title{
SYNTHESIS AND EVALUATION OF NOVEL BONE-TARGETING IBUPROFEN PRODRUG BASED ON DENDRITIC ASPARTIC ACID
}

\author{
YI ZHAO ${ }^{1, \#, *}, \mathrm{ZE} \mathrm{ZHAO}{ }^{2, \#}$, YAMIN CUI ${ }^{3, \#}, \mathrm{CHANGQING} \mathrm{CHEN}^{2}, \mathrm{CHANGWEI} \mathrm{XIE}^{2}$, \\ and YANG YANG ${ }^{1, *}$
}

\author{
${ }^{1}$ Department of Translational Medicine Center, the First Affiliated Hospital of Zhengzhou University, \\ Zhengzhou 450052, China \\ ${ }^{2}$ Department of Orthopedics, the First Affiliated Hospital of Henan Polytechnic University \\ (the Second People's Hospital of Jiaozuo City), Jiaozuo 454001, China \\ ${ }^{3}$ Zhengzhou Immuno Bio-Tech Co., Ltd, Zhengzhou 450016, China
}

\begin{abstract}
Bone diseases, such as osteoarthritis, osteomyelitis, are notoriously difficult diseases to treat due to the comparatively low blood flows in bone tissue. Ibuprofen is a well-known potent non-steroid anti-inflammatory drug (NSAID), which plays an important role in the treatment of osteoarthritis. However, its poor bone-targeting ability hinders its further application. Herein, several novel dendritic aspartic acid-modified ibuprofen prodrugs were designed and further synthesized. The stability of these prodrugs was investigated in buffer solutions and plasma, respectively. In addition, the solubility, hydroxyapatite (HAP) binding, cytotoxicity, acute toxicity, and bone targeting ability in vivo were all evaluated. All the novel prodrugs showed the superior physicochemical property in vitro. The bone-targeting study in vivo provided the evidence that these prodrugs could increase ibuprofen levels in bone tissue, among which the Ibu-Asp 8 showed the best affinity due to the increased aspartic acid residues conjugated to the drug. The dendritic Asp carriers were efficient as bone-targeting moieties, and the conjugation with ibuprofen ensured the increased accumulation of drugs in the bone region. In general, our findings provided a novel and effective drug for the treatment of bone diseases.
\end{abstract}

Keywords: bone targeting, ibuprofen, osteoarthritis, prodrug, dendritic aspartic acid

With the development of the medical level, society has begun entering into aging and the ratio of old people has increased dramatically in most countries (1). Meanwhile, bone diseases are becoming increasingly common (2-3). If not treated effectively, most of the diseases, especially osteoarthritis, may cause persistent pain and significantly lower the quality of patients' life. Osteoarthritis, the chronic inflammation of bones, is mainly treated by surgery, drug therapy, and non-drug therapy at present. However, its precise mechanism is still unclear (4).

Recently, non-steroidal anti-inflammatory drugs (NSAIDs) have been widely used for osteoarthritis treatment (5-6). Nevertheless, it often needs high dose and long-term use due to the low blood flows in bone tissue and low targeting ability of drugs. Although increasing the dose of drugs in osteoarthritis treatment could cause stronger side effects and more severe toxicity to the gastrointestinal tract, liver, and kidneys. Therefore, strategies that could effectively deliver drugs, such as ibuprofen, to the site of bone tissue are of great interest for osteoarthritis treatment (7-8).

Bone tissue is composed of inorganic salts (50-70\%), organic bone (20-40\%), water (5-10\%), and esters (1-5\%), and the inorganic compound hydroxyapatite (HAP) is known as the main component of bone, which has been used as a promising target of bone for selective drug delivery (9-11). In our previous report, it was found the acidic amino acids, especially glutamic oligopeptide, and aspartic (Asp) oligopeptide, had a superior affinity to the bone (12-13). The mechanism for the bone-targeting ability of these oligopeptides is that the multi-carboxy groups of peptides provide ionic interaction between negative charges and calcium ions in the HAP (14). Moreover, this affinity usually depends on the number of exposed amino acid residues. Compared with the linear peptide, the dendritic peptide has more carboxy groups outside, which could enhance the affinity to bone and the water solubility.

\footnotetext{
\# These authors contributed equally to this work

* Corresponding author: e-mail: zhaoyi0910@163.com (Y.Z.); yangyangbio@163.com (Y.Y.)
} 


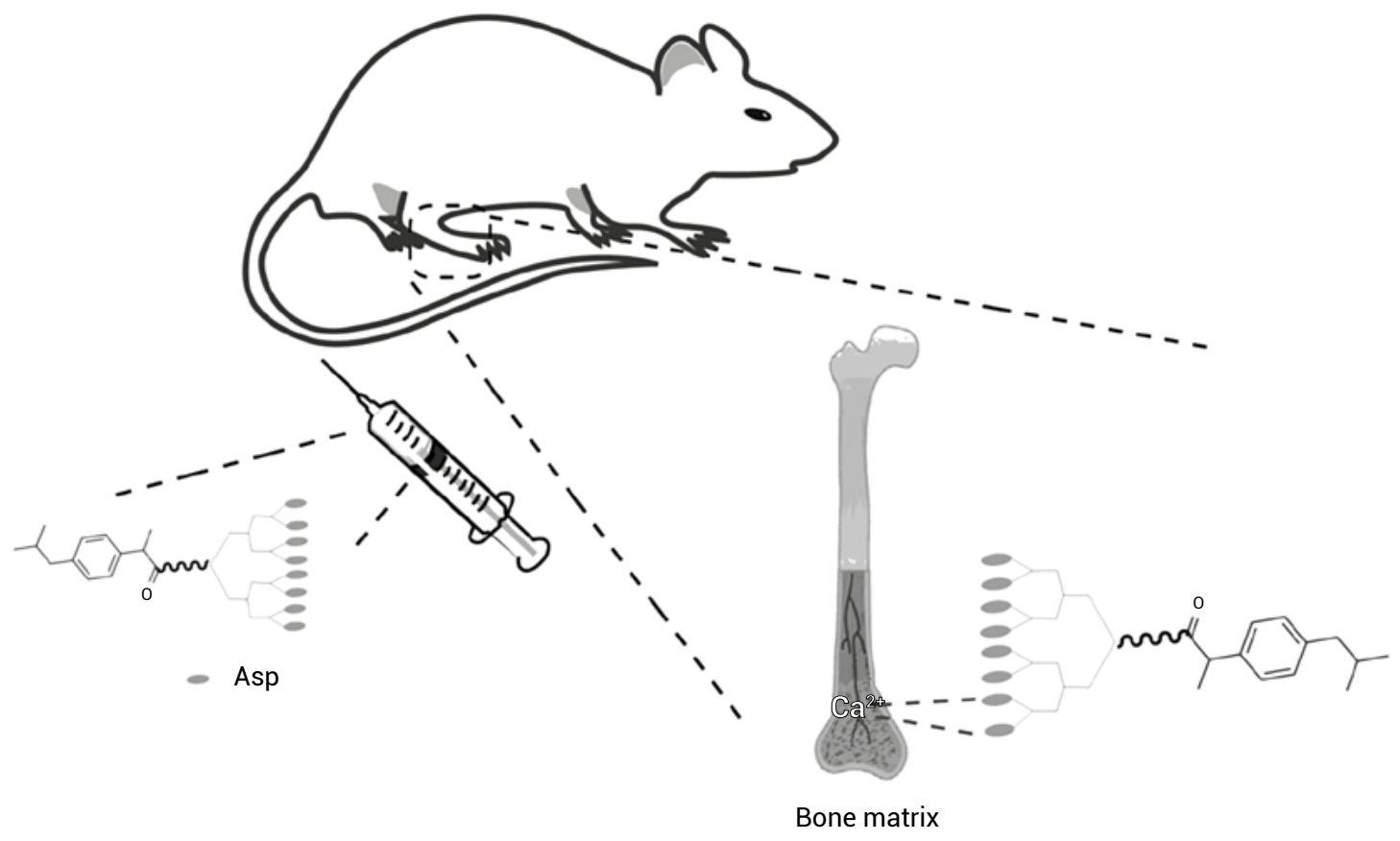

Figure 1. Schematic illustration of prodrug Ibu-Asp $\mathrm{p}_{8}$ to target bone.

Based on the affinity mechanism and the dendritic effect, we hypothesize that the more amino acid residues conjugated to the drug, the stronger affinity to bone exhibited. Over the past years, we have been working on designing bone-targeting drugs, especially based on the acidic amino acid, which is biocompatible, non-toxic, and biodegradable (2-3, 12-13). We are still exploring how to further heighten the bone targeting ability of drugs. In this study, a series of novel dendritic aspartic acid-modified ibuprofen prodrugs (Ibu-Asp ${ }_{1}, I_{b u-A s p}, I_{1 b u-A s p}$, and $\mathrm{Ibu}-\mathrm{Asp}_{8}$ ) were designed and synthesized. These prodrugs could utilize the dendritic Asp to target bone efficaciously (Figure 1). The stability of these prodrugs was investigated in buffer solutions and plasma, respectively. What's more, the solubility, hydroxyapatite (HAP) binding, cytotoxicity, acute toxicity, and bone targeting ability in vivo were also evaluated.

\section{MATERIALS AND METHODS}

\section{General Procedures}

All the starting materials, unless otherwise specified, were used from commercial resources. The thin-layer chromatography (TLC) was performed using precoated silica gel GF254 (0.2 $\mathrm{mm})$, and column chromatography was performed using silica gel (100200 mesh). Elemental analyses were performed by Atlantic Microlab (Atlanta, GA, USA). In this study, all the animal procedures were performed after being approved by the Experiment Animal Administrative Committee (P.R. China).

\section{Chemistry \\ Synthesis of compounds 3-8 (Figure 2)}

The synthesis of compounds 3-8 was reported in our previous report (13).

\section{Synthesis of compound 10 (dibenzyl \\ (2-(4-isobutylphenyl)propanoyl)aspartate)}

To a solution of ibuprofen $9(1.00 \mathrm{~g}, 4.85 \mathrm{mmol})$ in $\mathrm{CH}_{2} \mathrm{Cl}_{2}(30 \mathrm{~mL})$ were added isobutyl chloroformate (IBCF, $0.92 \mathrm{~mL}, 7.27 \mathrm{mmol}$ ) and 4-methylmorpholine (NMM, $0.81 \mathrm{~mL}, 7.27 \mathrm{mmol}$ ). After the mixture was stirred for $15 \mathrm{~min}$ at $-15^{\circ} \mathrm{C}$, $\mathrm{Asp}(\mathrm{OBn})$ OBn (2.28 g, $7.27 \mathrm{mmol})$ in $\mathrm{CH}_{2} \mathrm{Cl}_{2}(20 \mathrm{~mL})$ was added dropwise and the reaction mixture was stirred at r.t. for $6 \mathrm{~h}$. The solution was filtrated, and the filtrate was concentrated under reduced pressure. The residue was purified by column chromatography to get compound 10 (2.24 g, 92\%). The resulting compound purity was $95 \%$ detected by HPLC. ESI-MS $(\mathrm{m} / \mathrm{z})$ : calculated for $\mathrm{C}_{31} \mathrm{H}_{35} \mathrm{NO}_{5} \mathrm{Na}[\mathrm{M}+\mathrm{Na}]^{+} 524.24$, found 524.35. Elemental Analysis: C, 74.23; H, 7.03; $\mathrm{N}, 2.79$, found C, 74.35; H, 7.11; N, 2.68.

\section{Synthesis of prodrug Ibu-Asp1 ((2-(4-isobutylphenyl)propanoyl)aspartic acid)}

The compound 10 (1.50 g, $2.99 \mathrm{mmol})$ was dissolved in $\mathrm{CH}_{3} \mathrm{OH}(20 \mathrm{~mL})$, and $10 \% \mathrm{Pd} / \mathrm{C}(0.15 \mathrm{~g})$ was added into the solution. Subsequently, the mixture 


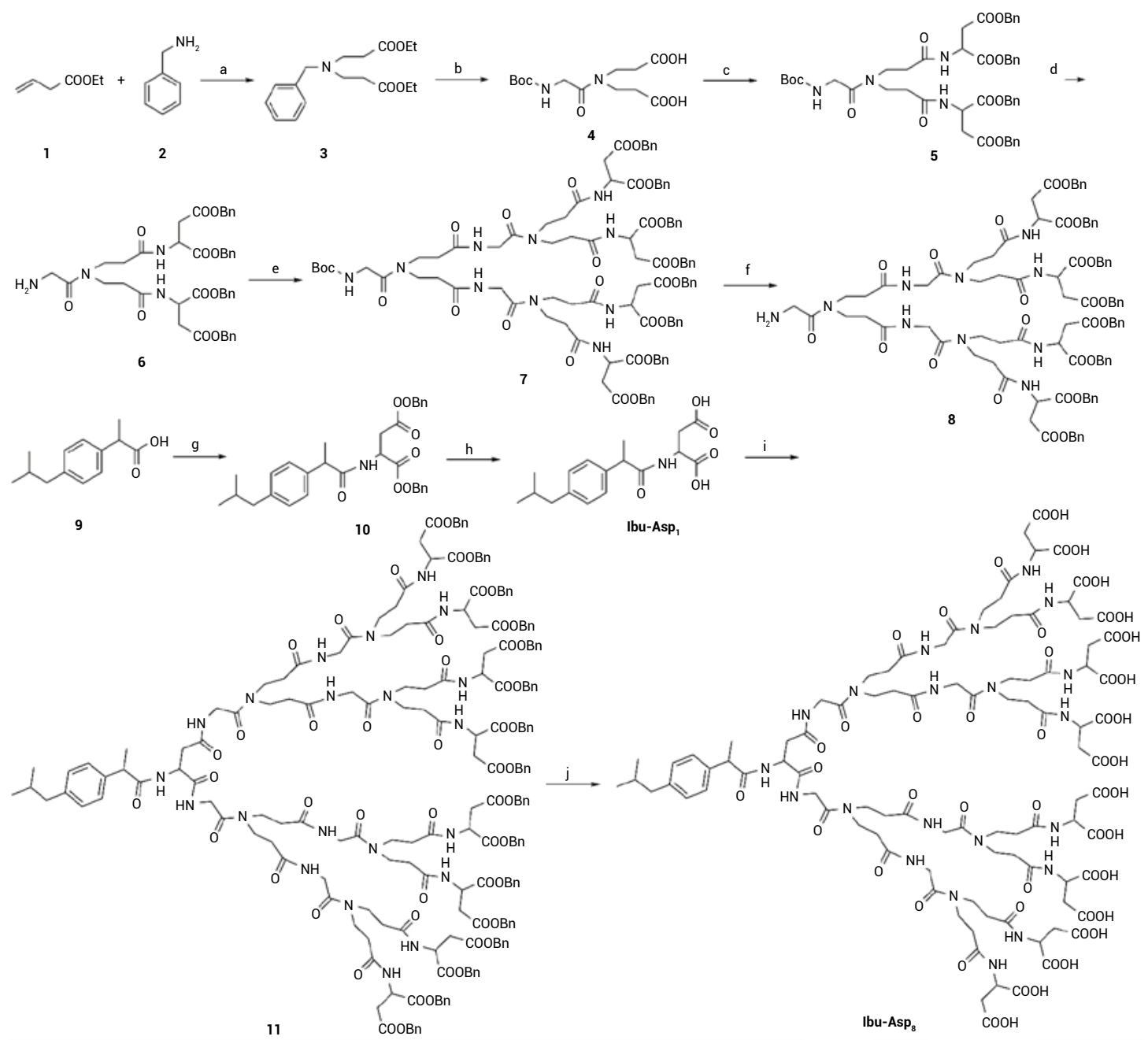

Figure 2. Synthesis of prodrugs Ibu-Asp $\mathrm{s}_{8}$ and Ibu-Asp. Reagents and conditions: (a) $\mathrm{C}_{2} \mathrm{H}_{5} \mathrm{OH}$, r.t. (b) i) $\mathrm{HCOONH}_{4}, \mathrm{Pd} / \mathrm{C}, \mathrm{CH}_{3} \mathrm{OH}$, r.t.; ii) Boc-Gly-OH, IBCF, $\mathrm{NMM},-15^{\circ} \mathrm{C}$ - r.t.; iii) $\mathrm{NaOH}, \mathrm{H}_{2} \mathrm{O}$, r.t. (c) $\mathrm{Asp}(\mathrm{OBn})-\mathrm{OBn}, \mathrm{EDCI}, \mathrm{HOBt}, \mathrm{CH}_{2} \mathrm{Cl}_{2}$, r.t. (d) $\mathrm{TFA}, \mathrm{CH}_{2} \mathrm{Cl}_{2}$, r.t. (e) 4, HBTU, DIPEA, $\mathrm{CH}_{2} \mathrm{Cl}_{2}$, r.t. (f) TFA, $\mathrm{CH}_{2} \mathrm{Cl}_{2}$, r.t. (g) $\mathrm{Asp}(\mathrm{OBn})-\mathrm{OBn}$, IBCF, $\mathrm{NMM}, \mathrm{CH}_{2} \mathrm{Cl}_{2}$, $-15^{\circ} \mathrm{C}$ - r.t. (h) $\mathrm{H}_{2}, \mathrm{Pd} / \mathrm{C}, \mathrm{CH}_{3} \mathrm{OH}$, r.t. (i) 8, IBCF, NMM, $\mathrm{CH}_{2} \mathrm{Cl}_{2},-15^{\circ} \mathrm{C}$ - r.t. (j) $\mathrm{H}_{2}, \mathrm{Pd} / \mathrm{C}, \mathrm{CH}_{3} \mathrm{OH}$, r.t.

was stirred at ambient temperature under $\mathrm{H}_{2}$ atmosphere for $1 \mathrm{~h}$ and then was filtered. The filtrate was concentrated and purified by flash column chromatography to yield prodrug Ibu-Asp 1 (0.96 g, 90\%). The resulting compound purity was $98 \%$ detected by HPLC. ESI-MS (m/z): calculated for $\mathrm{C}_{17} \mathrm{H}_{23} \mathrm{NO}_{5} \mathrm{Na}$ $[\mathrm{M}+\mathrm{Na}]^{+} 344.15$, found 344.22. Elemental Analysis: C, 63.54; H, 7.21; N, 4.36, found C, 63.68; H, 7.14; $\mathrm{N}, 4.45$.

\section{Synthesis of compound 11}

To a solution of prodrug Ibu-Asp $(0.30 \mathrm{~g}$, $0.93 \mathrm{mmol})$ in $\mathrm{CH}_{2} \mathrm{Cl}_{2}(10 \mathrm{~mL})$ were added IBCF (0.28 mL, $2.24 \mathrm{mmol})$ and NMM (0.25 $\mathrm{mL}$, $2.24 \mathrm{mmol})$. After the mixture was stirred for $15 \mathrm{~min}$ at $-15^{\circ} \mathrm{C}$, the dendron $8(4.18 \mathrm{~g}, 2.33 \mathrm{mmol})$ in $\mathrm{CH}_{2} \mathrm{Cl}_{2}(30 \mathrm{~mL})$ was added dropwise and the reaction mixture was stirred at r.t. for $20 \mathrm{~h}$. The solution was filtrated, and the filtrate was concentrated under reduced pressure. The residue was purified by column chromatography to give compound 11 (2.25 g, 62\%). The resulting compound purity was $96 \%$ detected by HPLC. MALDITOFMS (m/z): calculated for $\mathrm{C}_{209} \mathrm{H}_{231} \mathrm{~N}_{21} \mathrm{O}_{53} \mathrm{Na}[\mathrm{M}+\mathrm{Na}]^{+}$ 3905.59, found 3905.66. Elemental Analysis: C, 64.61; H, 5.99; N, 7.57, found C, 64.50; H, 5.86; N, 7.69.

\section{Synthesis of prodrug Ibu-Asp8}

The compound 11 (0.50 g, $0.13 \mathrm{mmol})$ was dissolved in $\mathrm{CH}_{3} \mathrm{OH}(10 \mathrm{~mL})$, and $10 \% \mathrm{Pd} / \mathrm{C}(0.20 \mathrm{~g})$ was added into the solution. Subsequently, the mixture was stirred at ambient temperature under $\mathrm{H}_{2}$ atmosphere for $5 \mathrm{~h}$, and then was filtered. The filtrate 


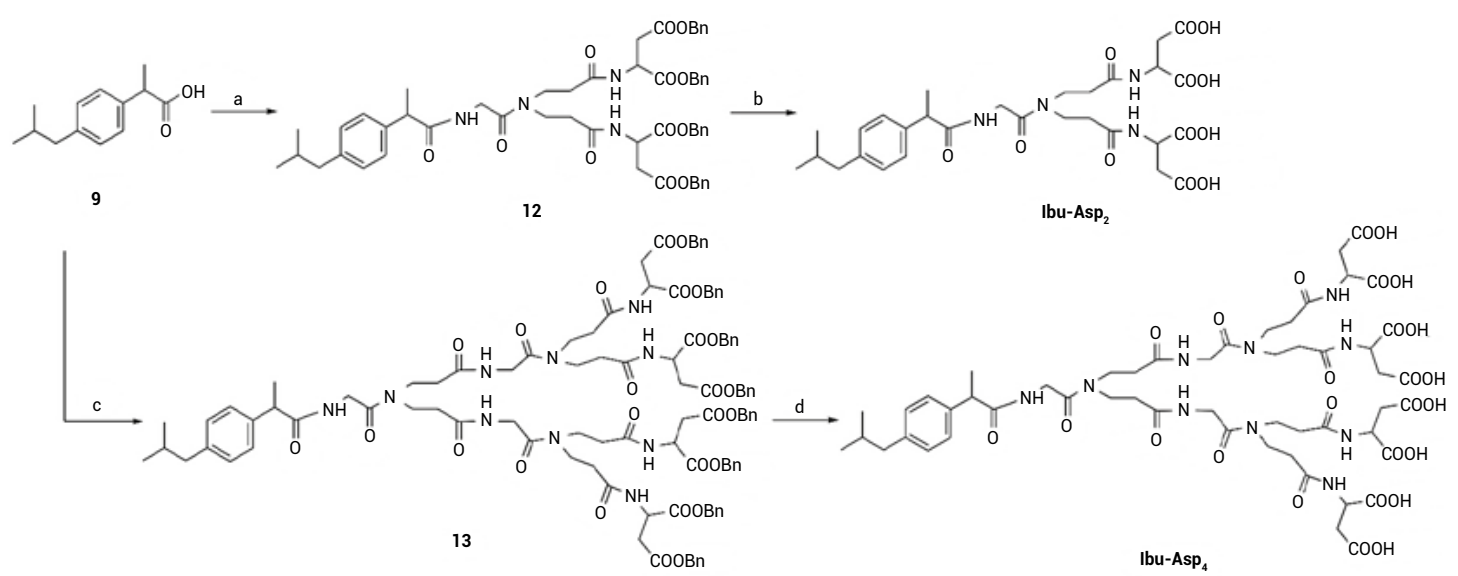

Figure 3. Synthesis of prodrugs Ibu- $\mathrm{Asp}_{2}$ and Ibu-Asp . Reagents and conditions: (a) 6, IBCF, NMM, $\mathrm{CH}_{2} \mathrm{Cl}_{2},-15^{\circ} \mathrm{C}-\mathrm{r.t.}$ (b) $\mathrm{H}_{2}, \mathrm{Pd} / \mathrm{C}$, $\mathrm{CH}_{3} \mathrm{OH}$, r.t. (c) 8, IBCF, NMM, $\mathrm{CH}_{2} \mathrm{Cl}_{2},-15^{\circ} \mathrm{C}$ - r.t. (d) $\mathrm{H}_{2}, \mathrm{Pd} / \mathrm{C}, \mathrm{CH}_{3} \mathrm{OH}$, r.t.

was concentrated and purified by flash column chromatography to yield prodrug Ibu-Asp $8(0.25 \mathrm{~g}, 80 \%)$. The resulting compound purity was $96 \%$ detected by HPLC. MALDITOF-MS (m/z): calculated for $\mathrm{C}_{97} \mathrm{H}_{135} \mathrm{~N}_{21} \mathrm{O}_{53} \mathrm{Na}[\mathrm{M}+\mathrm{Na}]^{+} 2464.84$, found 2464.75. Elemental Analysis: C, 47.69; H, 5.57; N, 12.04, found $\mathrm{C}, 47.55 ; \mathrm{H}, 5.50 ; \mathrm{N}, 12.17$.

\section{Synthesis of compound 12}

To a solution of ibuprofen $9(0.85 \mathrm{~g}, 4.12 \mathrm{mmol})$ in $\mathrm{CH}_{2} \mathrm{Cl}_{2}(10 \mathrm{~mL})$ were added IBCF $(0.68 \mathrm{~mL}$, $5.37 \mathrm{mmol})$ and NMM $(0.60 \mathrm{~mL}, 5.37 \mathrm{mmol})$. After the mixture was stirred for $15 \mathrm{~min}$ at $-15^{\circ} \mathrm{C}$, the dendron 6 (4.67 g, $5.77 \mathrm{mmol})$ in $\mathrm{CH}_{2} \mathrm{Cl}_{2}(20 \mathrm{~mL})$ was added dropwise and the reaction mixture was stirred at r.t. for $5 \mathrm{~h}$. The solution was filtrated, and the filtrate was concentrated under reduced pressure. The residue was purified by column chromatography to get compound 12 (3.20 g, 78\%). The resulting compound purity was $94 \%$ detected by HPLC. ESI-MS $(\mathrm{m} / \mathrm{z})$ : calculated for $\mathrm{C}_{57} \mathrm{H}_{64} \mathrm{~N}_{4} \mathrm{O}_{12} \mathrm{Na}[\mathrm{M}+\mathrm{Na}]^{+} 1019.44$, found 1019.57. Elemental Analysis: C, 68.66; H, 6.47; N, 5.62, found C, 68.54; H, 6.38; N, 5.74.

\section{Synthesis of prodrug Ibu-Asp2}

The compound $12(0.20 \mathrm{~g}, 0.20 \mathrm{mmol})$ was dissolved in $\mathrm{CH}_{3} \mathrm{OH}(10 \mathrm{~mL})$, and $10 \% \mathrm{Pd} / \mathrm{C}(30 \mathrm{mg})$ was added to the solution. Subsequently, the mixture was stirred at ambient temperature under $\mathrm{H}_{2}$ atmosphere for $2 \mathrm{~h}$ and then was filtered. The filtrate was concentrated and purified by flash column chromatography to yield prodrug Ibu-Asp $2(0.11 \mathrm{~g}, 88 \%)$. The resulting compound purity was $96 \%$ detected by HPLC. ESI-MS (m/z): calculated for $\mathrm{C}_{29} \mathrm{H}_{40} \mathrm{~N}_{4} \mathrm{O}_{12} \mathrm{Na}$ $[\mathrm{M}+\mathrm{Na}]^{+}$659.254, found 659.33. Elemental Analysis: C, 54.71; H, 6.33; N, 8.80, found C, 54.65; H, 6.44; N, 8.69.

\section{Synthesis of compound 13}

To a solution of ibuprofen $9(0.20 \mathrm{~g}, 0.97 \mathrm{mmol})$ in $\mathrm{CH}_{2} \mathrm{Cl}_{2}(10 \mathrm{~mL})$ were added IBCF $(0.16 \mathrm{~mL}$, $1.26 \mathrm{mmol}$ ) and NMM (0.14 mL, $1.26 \mathrm{mmol})$. After the mixture was stirred for $15 \mathrm{~min}$ at $-15^{\circ} \mathrm{C}$, the dendron 8 (2.44 g, $1.36 \mathrm{mmol})$ in $\mathrm{CH}_{2} \mathrm{Cl}_{2}(20 \mathrm{~mL})$ was added dropwise and the reaction mixture was stirred at r.t. for $6 \mathrm{~h}$. The solution was filtrated, and the filtrate was concentrated under reduced pressure. The residue was purified by column chromatography to get compound 13 (1.33 g, 69\%). The resulting compound purity was $93 \%$ detected by HPLC. MALDITOF-MS (m/z): calculated for $\mathrm{C}_{109} \mathrm{H}_{122} \mathrm{~N}_{10} \mathrm{O}_{26} \mathrm{Na}[\mathrm{M}+\mathrm{Na}]^{+}$2009.84, found 2009.77. Elemental Analysis: C, 65.85; H, 6.19; N, 7.04, found C, 65.73; H, 6.31; N, 6.92.

\section{Synthesis of prodrug Ibu-Asp4}

The compound $13(0.10 \mathrm{~g}, 0.05 \mathrm{mmol})$ was dissolved in $\mathrm{CH}_{3} \mathrm{OH}(10 \mathrm{~mL})$, and $10 \% \mathrm{Pd} / \mathrm{C}(20 \mathrm{mg})$ was added to the solution. Subsequently, the mixture was stirred at ambient temperature under $\mathrm{H}_{2}$ atmosphere for $3 \mathrm{~h}$ and then was filtered. The filtrate was concentrated and purified by flash column chromatography to yield prodrug Ibu-Asp 8 (43 mg, 67\%). The resulting compound purity was $95 \%$ detected by HPLC. MALDITOF-MS (m/z): calculated for $\mathrm{C}_{53} \mathrm{H}_{74} \mathrm{~N}_{10} \mathrm{O}_{26} \mathrm{Na}[\mathrm{M}+\mathrm{Na}]^{+} 1289.47$, found 1289.40 . Elemental Analysis: C, 50.23; H, 5.89; N, 11.05, found $\mathrm{C}, 50.38 ; \mathrm{H}, 5.76 ; \mathrm{N}, 11.17$.

\section{Stability of prodrugs in phosphate buffer and plasma}

The high-performance liquid chromatography (HPLC) employed was an Agilent 1100 HPLC liquid chromatographic system. The analysis was carried out on a Waters XTerra RP18 column 
(250 $\mathrm{mm} \times 4.6 \mathrm{~mm}, 5 \mu \mathrm{m})$. The mobile phase was composed of methanol/water (70: 30$)$, and the $\mathrm{pH}$ was adjusted to 3.0 with $10 \%$ phosphoric acid. The UV wavenumber was $265 \mathrm{~nm}$ and the flow rate was set at $1.0 \mathrm{~mL} / \mathrm{min}$ with a $20 \mu \mathrm{L}$ injection volume.

The chemical stability of the prodrugs including Ibu-Asp , Ibu-Asp $_{2}$, Ibu-Asp , and Ibu-Asp $_{8}$, was determined in vitro through incubating in the indicated phosphate buffers ( $\mathrm{pH} 2.5,5.0,7.4$, and 8.0), respectively. In general, $1 \mathrm{~mL}$ of the prodrugs methanol solution $(500 \mu \mathrm{M})$ was added into $4 \mathrm{~mL}$ different buffer separately with the final concentration at $100 \mu \mathrm{M}$. The entire system was kept at $37^{\circ} \mathrm{C}$ with continuous shaking at $50 \mathrm{rpm}$. The medium sample $(200 \mu \mathrm{L})$ was taken at the predetermined time points $(0,1,2,4,6,12,24,36$, and $48 \mathrm{~h})$ and then it was replaced with an equal volume of fresh medium. These samples were analyzed by the aforementioned HPLC method.

What's more, we also incubated these prodrugs in plasma to investigate their metabolic stability. In brief, $1 \mathrm{~mL}$ of the prodrugs methanol solution $(500 \mu \mathrm{M})$ was added into $4 \mathrm{~mL}$ plasma (Gibco, USA) with the final concentration at $100 \mu \mathrm{M}$. The entire system was kept at $37^{\circ} \mathrm{C}$ with continuous shaking at $50 \mathrm{rpm}$. The medium sample $(200 \mu \mathrm{L})$ was taken at the predetermined time points $(0,1,2$, $4,6,12,24,36$, and $48 \mathrm{~h}$ ) and then it was replaced with an equal volume of fresh medium. These samples were monitored by the HPLC method described above.

\section{Solubility assessment}

The solubility of the prodrugs (Table 2) was investigated in PBS at $\mathrm{pH}$ 7.4. In general, excessive amounts of the prodrugs were added into $2 \mathrm{~mL} \mathrm{PBS}$, respectively. And the mixtures were kept at $37^{\circ} \mathrm{C}$ with continuous shaking at $200 \mathrm{rpm}$ for $30 \mathrm{~min}$. After centrifugation at $12000 \mathrm{rpm}$ for $20 \mathrm{~min}$, the drug in the supernatant was monitored by the HPLC method described above.

\section{In vitro HAP binding assay}

To determine the binding ability (Figure 4) of these prodrugs to bones, an in vitro HAP binding assay was set up using the method described in our previous report $(2,12)$. Briefly, the different prodrugs were dissolved in $1 \mathrm{~mL}$ PBS with the concentration at $5 \mu \mathrm{M}$ and incubated with $20 \mathrm{mg}$ HAP (Aladdin, China) in tubes. The mixture was shaken gently at $37^{\circ} \mathrm{C}$. At the predetermined time ( $1 \mathrm{~h}$ or $24 \mathrm{~h})$, the unbound prodrug was separated from the mixture by centrifugation at $5000 \mathrm{rpm}$ for $3 \mathrm{~min}$ and quantified through
HPLC. The binding efficiency was calculated by HAP binding rate $(\%)=\left(\mathrm{C}_{0}-\mathrm{C}\right) / \mathrm{C}_{0} \times 100 \%$, where $\mathrm{C}_{0}$ is the concentration at the beginning and $\mathrm{C}$ is the concentration of unbound prodrug determined by HPLC.

\section{Cytotoxicity evaluation}

The cytotoxicity of the synthesized prodrugs (Ibu-Asp ${ }_{1}$, Ibu-Asp $_{2}$, Ibu-Asp $_{4}$, and Ibu-Asp I $_{8}$ ) was evaluated on human embryonic kidneys (HEK293, Chinese Academy of Sciences, China) cells using (3,4,5-dimethylthiazol-yl)-2,5-diphenyltetrazolium (MTT) assay. The cells were incubated in Dulbecco's Modified Eagles Medium (DMEM), supplemented with $10 \%$ fetal bovine serum (FBS, Gibco), $100 \mathrm{U} / \mathrm{ml}$ penicillin (Aladdin, China), and streptomycin (Aladdin, China). The cells were cultured at $37^{\circ} \mathrm{C}$ in a $5 \% \mathrm{CO}_{2}$ humidified environment incubator.

In this process, the cells were seeded into 96-well plates. In each well, a density of approximately 1000 cells was maintained at $37^{\circ} \mathrm{C}$ for about $24 \mathrm{~h}$. Then these drugs were diluted to predetermined concentrations $(1,10,20,50$, and $100 \mu \mathrm{M})$ with phosphate-buffered saline (PBS). The diluted solutions were then added to each well. After $24 \mathrm{~h}$ of incubation, the cells were treated with MTT $(20 \mu \mathrm{L}, 5.0 \mathrm{mg} / \mathrm{mL})$ for $4 \mathrm{~h}$. Then, they were thrice washed with PBS. These cells were then isolated using $200 \mu \mathrm{L}$ DMSO. The OD value of the samples was measured at a wavelength of $490 \mathrm{~nm}$ on the microplate reader.

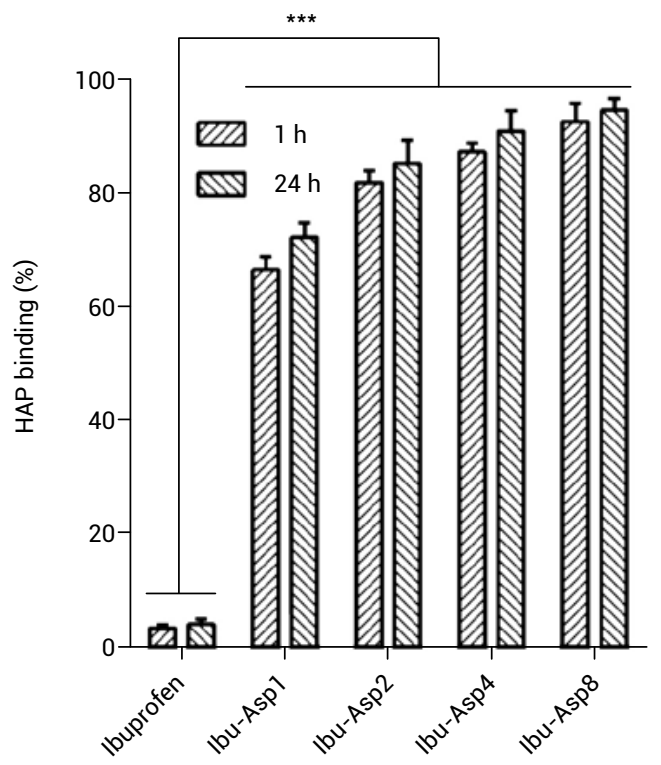

Figure 4. Percentage of prodrugs bound to HAP. $* * * \mathrm{P}<0.001$. $(\mathrm{n}=3$, mean $\pm \mathrm{SD})$ 


\section{Acute toxicity in vivo}

The acute toxicity of these prodrug formulations was investigated using Kunming mice weighing 20-24 g. The mice were randomly divided into five groups $(n=10)$. Before the study, the animals abstained from food for $12 \mathrm{~h}$ but they had free access to water. The different prodrugs were injected into animals at the dose of $100,500,1000,5000 \mathrm{mg} / \mathrm{kg}$ (calculated as ibuprofen, in PBS) body weight via tail vein. After $24 \mathrm{~h}$, the dead animals were counted in each group. The animals were under observation for another two weeks for any morbidities or mortalities.

\section{Targeting bone in vivo}

The evaluation of the bone-targeting ability of these Asp-modified prodrugs was investigated according to our previously reported methods (3). Generally, the Kunming mice weighing 20-24 g were randomly divided into five groups $(\mathrm{n}=3)$. All animal experiments were performed by following institutional guidelines and approved by the Animal Ethical Experimentation Committee. The animals were kept in well-spaced ventilated cages, and they were fed a healthy and balanced diet. Before injecting the animals, we starved them for $12 \mathrm{~h}$. However, free access to water was provided during the starvation period. A tissue distribution study was conducted in rats to evaluate and compare the bone targeting potential of the prodrugs. Ibuprofen and ibuprofen prodrugs (50 $\mu \mathrm{mol} / \mathrm{kg}$, calculated as ibuprofen) dissolved in PBS were injected into the tail vein of each mice.

At the indicated time-points $(1,2,4$, and $8 \mathrm{~h})$, the mice were sacrificed, and the lower tibia bones were removed and rinsed with saline. Then, the tibia bone tissues were dried on a filter paper and subsequently homogenized with twice the amount of saline. After vortex with an equal volume $(200 \mu \mathrm{L})$ of methanol for five minutes, $10 \mu \mathrm{L} \mathrm{NaOH}$ solution $(5 \mathrm{~mol} / \mathrm{L})$ was added into the homogenate $(200 \mu \mathrm{L})$. Then, the hydrolysis was carried out for $10 \mathrm{~min}$ at room temperature to release ibuprofen from the prodrugs. Thereafter, the hydrochloric acid solution $(10 \mu \mathrm{L}, 5 \mathrm{~mol} / \mathrm{L})$ was added to neutralize the $\mathrm{NaOH}$. After vortex for another $5 \mathrm{~min}$, the mixture was centrifuged at $13000 \mathrm{rpm}$ for $10 \mathrm{~min}$ and the supernatant was dried by nitrogen gas flow. Subsequently, the residues were dissolved in $200 \mu \mathrm{L}$ methanol and mixed by the vortex. The solution was centrifuged at $13000 \mathrm{rpm}$ for $10 \mathrm{~min}$, and $20 \mu \mathrm{L}$ of the supernatant was injected into the HPLC system for analysis.

\section{Statistical analysis}

GraphPad Prism 5.0 software (GraphPad, USA) was used for statistical analysis. All data in this study were represented as mean \pm standard deviation (SD). Statistical comparisons were performed by analysis of variance (ANOVA) for multiple groups followed by Student's t-test. The significance was defined as follows: ***P $<0.001$.

\section{RESULTS}

\section{Chemistry}

The synthesis procedure of prodrugs Ibu$\mathrm{Asp}_{8}$ and Ibu-Asp $\mathrm{p}_{1}$ was shown in Figure 2. The bonetargeting dendritic aspartic acid $\left(\mathrm{Asp}_{2}\right.$ and $\left.\mathrm{Asp}_{4}\right)$ derivatives were prepared according to our previously reported work (13). Generally, the ethyl acrylate $\mathbf{1}$ and benzylamine 2 underwent six steps to generate the dendritic intermediate 6 (13), which further then underwent two steps to yield the dendritic intermediate 8 (13). What's more, the commercially available ibuprofen 9 was coupled with Asp(OBn)-OBn to give the compound $\mathbf{1 0}$, which was debenzylated with $10 \% \mathrm{Pd} / \mathrm{C}$ to generate the prodrug Ibu-Asp . $_{1}$

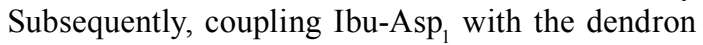
8 under IBCF/NMM was performed to give the compound 11, which was deprotected to obtain the prodrug Ibu-Asp.

The synthetic routes of prodrugs Ibu-Asp $\mathrm{A}_{2}$ and Ibu-Asp ${ }_{4}$ were outlined in Figure 3. In brief, the ibuprofen was respectively conjugated with the intermediate $\mathbf{6}$ or $\mathbf{8}$ in the presence of IBCF and NMM to yield compound $\mathbf{1 2}$ or $\mathbf{1 3}$, which were then debenzylated with $10 \% \mathrm{Pd} / \mathrm{C}$ to give the desired ligand prodrugs Ibu-Asp $\mathrm{And}_{2}$ and-Asp .

\section{Stability and solubility of prodrugs}

Stability study of these prodrugs was performed in various phosphate buffers to simulate the different physiological environments. As shown in Table 1 , the pseudo-first-order rate constants $\left(\mathrm{K}_{\text {disapp }}\right)$ and half-lives $\left(t_{1 / 2}\right)$ of these prodrugs in PBS were calculated by linear regression of the peak area against time. It could be seen that all the prodrugs were highly stable in $\mathrm{pH} 7.4$ buffer solution, wherein its $\mathrm{t}_{1 / 2}$ value was more than $40 \mathrm{~h}$, moderately stable in $\mathrm{pH} 5.0$, and unstable in $\mathrm{pH} 2.5$ and 8.0 buffer solution. What's more, the metabolic stability of the prodrugs was also investigated in mice plasma at $37^{\circ} \mathrm{C}$. Interestingly, all the prodrugs exhibited considerable stability in mice plasma, wherein its $t_{1 / 2}$ value was about 4.8-6.6 h. All the results indicated that the superior stability of these prodrugs ensured the long circulation in plasma and 
Table 1. Stability of ibuprofen prodrugs at $37^{\circ} \mathrm{C}$.

\begin{tabular}{|c|c|c|c|c|c|c|c|c|}
\hline \multirow{2}{*}{ Media } & \multicolumn{2}{|c|}{ Ibu-Asp $_{1}$} & \multicolumn{2}{c|}{ Ibu-Asp $_{2}$} & \multicolumn{2}{c|}{ Ibu-Asp $_{4}$} & \multicolumn{2}{c|}{ Ibu-Asp $_{8}$} \\
\cline { 2 - 9 } & $\mathrm{K}_{\text {disapp }}\left(\mathrm{h}^{-1}\right)$ & $\mathrm{t}_{1 / 2}(\mathrm{~h})$ & $\mathrm{K}_{\text {disapp }}\left(\mathrm{h}^{-1}\right)$ & $\mathrm{t}_{1 / 2}(\mathrm{~h})$ & $\mathrm{K}_{\text {disapp }}\left(\mathrm{h}^{-1}\right)$ & $\mathrm{t}_{1 / 2}(\mathrm{~h})$ & $\mathrm{K}_{\text {disapp }}\left(\mathrm{h}^{-1}\right)$ & $\mathrm{t}_{1 / 2}(\mathrm{~h})$ \\
\hline $\mathrm{pH} 2.5$ & $6.7 \times 10^{-2}$ & 10.4 & $5.0 \times 10^{-2}$ & 13.8 & $7.1 \times 10^{-2}$ & 9.7 & $6.0 \times 10^{-2}$ & 11.5 \\
\hline $\mathrm{pH} 5.0$ & $2.7 \times 10^{-2}$ & 25.8 & $2.9 \times 10^{-2}$ & 23.6 & $2.5 \times 10^{-2}$ & 27.4 & $2.3 \times 10^{-2}$ & 30.1 \\
\hline $\mathrm{pH} 7.4$ & $1.7 \times 10^{-2}$ & 40.5 & $1.5 \times 10^{-2}$ & 46.3 & $1.5 \times 10^{-2}$ & 45.1 & $1.4 \times 10^{-2}$ & 47.8 \\
\hline pH 8.0 & $4.3 \times 10^{-2}$ & 16.2 & $4.5 \times 10^{-2}$ & 15.4 & $3.7 \times 10^{-2}$ & 18.6 & $4.0 \times 10^{-2}$ & 17.2 \\
\hline Plasma & $14.4 \times 10^{-2}$ & 4.8 & $13.3 \times 10^{-2}$ & 5.2 & $11.3 \times 10^{-2}$ & 6.1 & $10.5 \times 10^{-2}$ & 6.6 \\
\hline
\end{tabular}

enough time to reach the bone tissue before they were metabolized.

The results of the solubility assessment were presented in Table 2, which clearly demonstrated the solubility of the prodrugs. It was revealed that the dendritic aspartic acid could significantly increase the solubility of ibuprofen. And this highly increased solubility could be attributed to the surface carboxy groups that were available to interact with water molecules. The decoration of dendritic aspartic acid increased the solubility of ibuprofen to 1.05$3.89 \mathrm{mM}$ in water, which indicated that the hydrophilic dendrimers were effective vehicles to heighten the solubility of insoluble drugs. It also revealed that the $\mathrm{Asp}_{8}$ had more carboxy groups at the surface area to interact with water molecules with higher ability than that of other groups. To sum up, all the results suggested that dendritic Asp is a superior strategy to enhance the solubility and delivery capacity of poorly water-soluble drugs.

\section{In vitro HAP binding assay}

As shown in Figure 4, it was revealed that all of the Asp-modified ibuprofen prodrugs exhibited excellent HAP affinity, whereas the free ibuprofen was at best negligibly bound, which suggested that these dendritic aspartic acid moieties played a crucial role in the HAP binding process. The binding rates of these prodrugs evidently exceeded $60 \%$, especially for the group of Ibu-Asp $\mathrm{p}_{8}$ with binding rates of over $90 \%$. In addition, the results in Figure 4 also showed that the binding rates dramatically culminated rapidly. And the number of Asp that modified on the drug was correlated with the binding efficiency. Besides, no significant difference was found between the HAP affinity within $1 \mathrm{~h}$ and $24 \mathrm{~h}$. All the results suggested that the bone-targeting property of ibuprofen was

Figure 5. Cytotoxicity of Asp-modified prodrugs against HEK293 cells. $(\mathrm{n}=3$, mean \pm SD $)$
Table 2. Water solubility of prodrugs in PBS.

\begin{tabular}{|l|c|c|}
\hline & Number of -COOH & Water solubility (mM) \\
\hline Ibuprofen & 1 & 0.22 \\
\hline Ibu-Asp & 2 & 1.05 \\
\hline Ibu-Asp & 4 & 1.80 \\
\hline Ibu-Asp $_{4}$ & 8 & 2.57 \\
\hline Ibu-Asp & 16 & 3.89 \\
\hline
\end{tabular}

enhanced, which was attributed to the modification of dendritic Asp.

\section{Cytotoxicity evaluation}

Cytotoxicity is one of the most critical factors to be considered in selecting a carrier for drug delivery in the biological system. In this study, the natural amino acids (Asp) were chosen to conjugate with ibuprofen to target bone tissue. As shown in Figure 5, all the prodrugs did not exhibit any toxicity on HEK293 cells at the dose level of $1-100 \mu \mathrm{M}$, which suggested that the dendritic

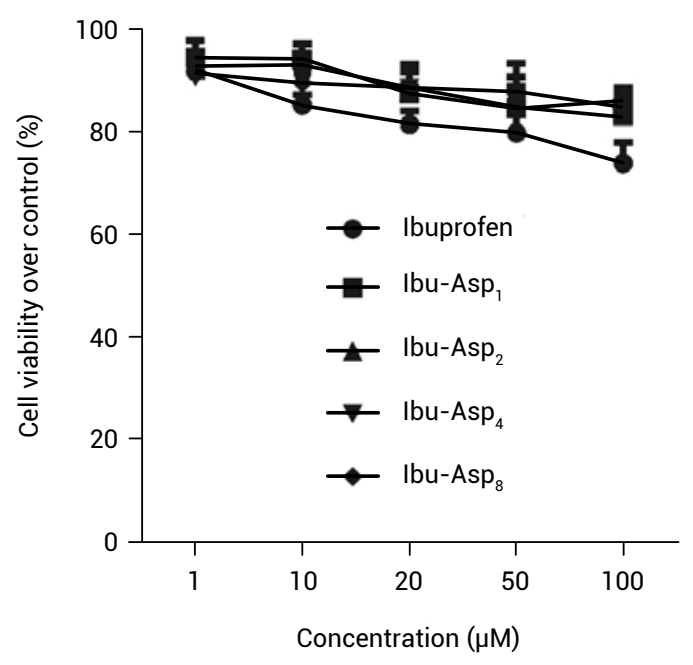




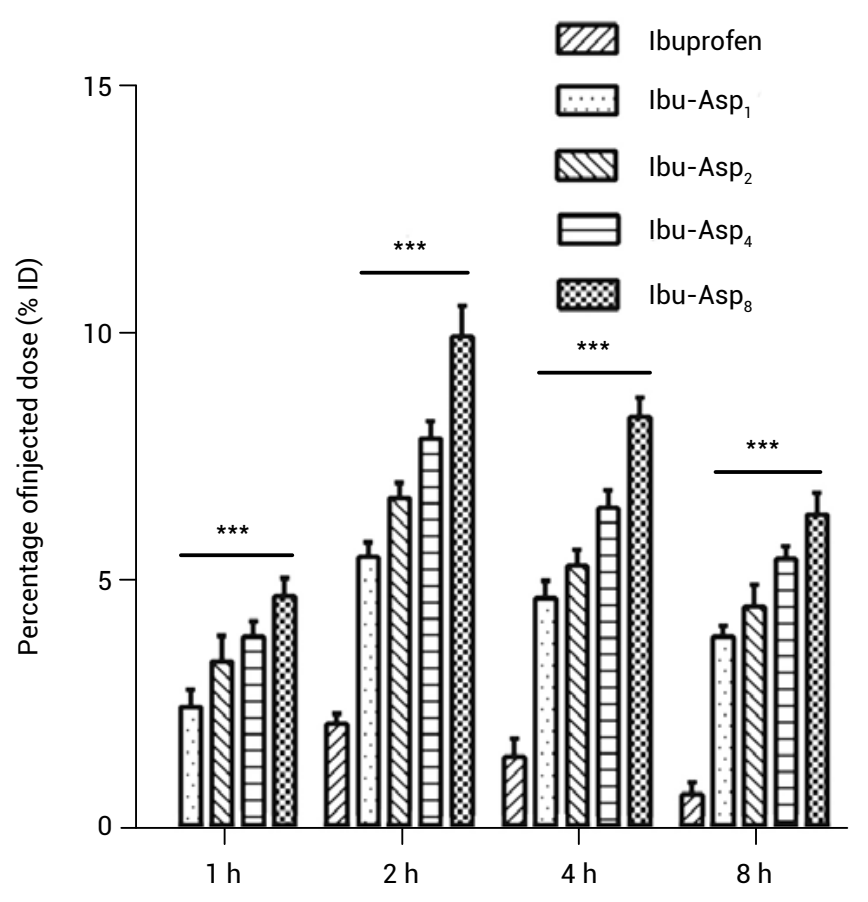

Figure 6. Ibuprofen concentration after injection of free ibuprofen, Ibu-Asp ${ }_{1}$, Ibu-Asp ${ }_{2}$ Ibu-Asp ${ }_{4}$, and Ibu-Asp ${ }_{8}$ in the femur tissue. $* * * \mathrm{P}<0.001,(\mathrm{n}=5$, mean $\pm \mathrm{SD})$. ND means not detected in the ibuprofen group at $1 \mathrm{~h}$.

aspartic acid was non-toxic or low-toxic in tested concentrations.

\section{Acute toxicity}

It is important to investigate the acute toxicity in vivo to ensure the biocompatibility of these prodrugs. The drugs were injected into the mice respectively with different doses to establish their safety for application in drug delivery. After 14 days of observation, no serious adverse effects or signs of morbidity were found in any animal in all groups, which confirmed the safety of the Asp-modified prodrugs.

\section{Targeting bone in vivo}

To further make sure whether the dendritic Asp-modified prodrugs could target bone tissue, the bone-targeting ability in vivo was investigated at the fixed time intervals after injection. The ibuprofen was quantified calculated as the percentage of injected dose (\%ID). As shown in Figure 6, modification of dendritic Asp could obviously enhance the accumulation of ibuprofen in the femur, which was due to the outstanding bone-targeting ability of aspartic acid. And it is interesting to note that an increasing trend was exhibited with the increase of the number of aspartic acid residues. The concentrations of ibuprofen in the Ibu-Asp , Ibu-Asp $_{2}$, Ibu-Asp , $_{4}$ and Ibu$\mathrm{Asp}_{8}$ groups were 2.7, 3.3, 3.9, and 5.0 times higher than that of the ibuprofen group, respectively. This effect was attributed to the peculiarity of Asp, which had a strong affinity to bones. Overall, the dendritic Asp carriers were efficient as bonetargeting moieties, and the conjugation with ibuprofen ensured the increased accumulation of the drug in the bone region, which could reduce the terrible side-effects of the drug on other organs. In general, the results provided a novel and effective entry to the development of bonetargeting drugs.

\section{DISCUSSION}

Bone diseases are the most common degenerative disease in bone tissue (15). The incidence of osteoarthritis has dramatically increased all across the world. This disease has affected about $10 \%$ of people over the age of 60 . Osteoarthritis is mainly characterized as joint pain and stiffness, which could seriously affect patients' health and quality of life (16). It is also one of the main causes that result in disability. Currently, the treatment for osteoarthritis is usually to relieve pain, prevent and delay disease progression, protect joint function and improve quality of life (17). There is no radical treatment for it and the pathogenesis of osteoarthritis is still unclear at present.

In recently, many studies have reported that NSAIDs, especially ibuprofen, have been widely used in treating osteoarthritis (18-19). Owing to the low blood flows in bone tissue and the low targeting ability of ibuprofen, it is prescribed in higher doses to achieve satisfactory therapeutic effects, which may cause strong side effects and more severe toxicity to the gastrointestinal tract, liver, and kidneys. Therefore, new promising strategies must be developed to effectively deliver drugs to the site of bone tissue for the treatment of osteoarthritis.

In order to develop an efficient bone-targeting drug delivery system to greatly enhance the capacity of ibuprofen to target bone tissue, a series of novel dendritic aspartic acid-modified ibuprofen prodrugs were designed and synthesized in this study. These prodrugs had superior properties, such as the moderate stability in PBS and plasma, which could ensure the drugs had plenty of time to reach the bone before being hydrolyzed. Furthermore, it was also found that the prodrugs had low cytotoxicity both in vitro and 
in vivo, indicating that these prodrug drug delivery systems were safe and non-toxic to be further used in vivo. Moreover, the Asp-modified prodrugs had an obvious increase in targeting ability to bone in vitro and in mice, and this targeting capacity was positively correlated with the number of Asp residues.

Interestingly, this work proves that the dendritic aspartic acid was a superior carrier and enhances the delivery of ibuprofen to target the bone tissue. All the results in vitro and in vivo suggested that these prodrugs indeed had the potential to improve the clinical therapeutic effects of osteoarthritis. The results are very promising and more work is in progress, that is, better animal models are being developed for comprehensive evaluations in vivo. We will surely report the biological activities of this conjugate in due time.

\section{CONCLUSION}

Site-specific bone drug delivery via targeting function approach has generated considerable interest. This strategy not only enhances the potency of drugs but also diminishes their side effects and toxicity. Here, several novel dendritic prodrugs were designed and synthesized for bone-targeting effects. These drugs possess good biosecurity and high HAP binding efficiency in vitro. And the results in vivo showed that all the prodrugs could obviously enhance the accumulation of ibuprofen in the femur, among which, the Ibu-Asp 8 groups showed the concentration of ibuprofen was 5.0 times higher than that of the ibuprofen group. Therefore, the results provided a promising and effective entry to the development of bone-targeting drugs.

\section{Acknowledgment}

This work was supported by the National Natural Science Foundation of China (Nos. 81903448 \& 31900502), the Fundamental Research Funds for the Universities of Henan Province (No. NSFRF210319).

\section{Conflict of interest}

The authors declare no competing financial interest.

\section{REFERENCES}

1. Detaille S.I., de Lange A., Engels J., Pijnappels M., Hutting N., et al.: Front. Psychol. 11, 535353 (2020).

2. Zhao Y., He D., Ma L., Guo L.: Lett. Drug Des. Discov. 12, 585 (2015).

3. Zhao Z., Zhao Y., Xie C., Chen C., Lin D., et al.: Chem. Phys. Lipids 223, 104785 (2019).

4. Zhu X., Chan Y.T., Yung P.S.H., Tuan R.S., Jiang Y.: Front. Cell Dev. Biol. 8, 607764 (2020).

5. Paglia D.N., Kanjilal D., Kadkoy Y., Moskonas S., Wetterstrand C., et al.: J. Orthop. Res. 2020, pages 8 (2020).

6. Baranowski D.C., Buchanan B., Dwyer H.C., Gabriele J.P., Kelly S., et al.: J. Pain Res. 11, 2809 (2018).

7. Jia H., Kerr L.L.: J. Pharm. Sci. 102, 2341 (2013).

8. O’Connor J.P., Capo J.T., Tan V., Cottrell J.A., Manigrasso M.B., et al.: Acta Orthop. 80, 597 (2009).

9. Nadar R.A., Franssen G.M., Van Dijk N.W.M., Codee-van der Schilden K., de Weijert M., et al.: Mater. Today Bio 9, 100088 (2021).

10. Cheng X., Wei J., Ge Q., Xing D., Zhou X., et al.: Drug Deliv. 28, 37 (2021).

11. Li C., Wang J., Wang Y., Gao H., Wei G., et al.: Acta Pharm. Sin. B 9, 1145 (2019).

12. Yang Y., Zhao Z., Xie C., Zhao Y.: Chem. Phys. Lipids 228, 104882 (2020).

13. Zhao Z., Xie C., Chen C., Zhao Y.: Chem. Phys. Lipids 226, 104832 (2020).

14. Sarig S.: Bone 35, 108 (2004).

15. Barr A.J., Campbell T.M., Hopkinson D., Kingsbury S.R., Bowes M.A., et al.: Arthritis Res. Ther. 17, 228 (2015).

16. Yu Y.K., Chen T.H., Liu Z., Tu D.P., Peng Y., et al.: Life Res. 4, 20 (2021).

17. Kou L., Xiao S., Sun R., Bao S., Yao Q., et al.: Drug Deliv. 26, 870 (2019).

18. Honvo G, Leclercq V, Geerinck A, Thomas T, Veronese N, et al.: Drugs Aging 36, 45 (2019).

19. Gordo A.C., Walker C., Armada B., Zhou D.: J. Int. Med. Res. 45, 59 (2017). 